\section{Hvordan kan fysiske hjerneprosesser gi opphav til bevissthet?}

\section{Gundersen S}

Bevissthet og fysisk virkelighet

158 s, ill. Oslo: Unipub, 2008. Pris NOK 229 ISBN 978-82-7477-365-3

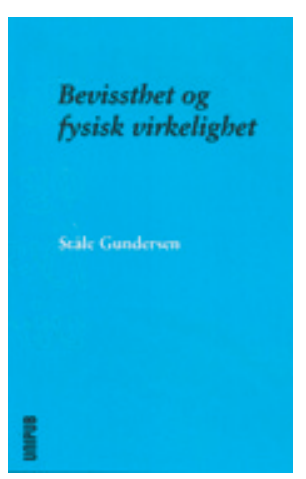

Vår bevissthet skyldes hjerneprosesser og omfatter hele vår subjektive verden: Alt vi sanser, føler, tenker og husker. Men hvordan kan fysiske prosesser i hjernen gi opphav til vår bevissthet - et fenomen som ikke synes å passe inn i vårt naturvitenskapelige verdensbilde? De siste årene har brakt en ny bølge av interesse for dette dype mysteriet. Nye metoder for kartlegging av hjerneaktivitet hos våkne mennesker har tent håp om fremgang. ( $\mathrm{Og}$ endelig har vi funnet plass til dette temaet også i medisinstudiet, i Oslo.) Men kan mysteriet løses med naturvitenskapelige metoder?

Ståle Gundersen, som er førsteamanuensis i filosofi ved Universitetet i Stavanger, tar for seg disse store spørsmålene. Han gir en god oversikt over sentrale filosofiske teorier, og presenterer så sitt eget syn. Forfatteren henvender seg til et bredt publikum, inkludert studenter og forskere innen filosofi, psykologi, naturvitenskap og samfunnsfag, og er både konsis og dyptpløyende. Spesielt interessant er det at Gundersen gjør seg til talsmann for et relativt radikalt filosofisk standpunkt som man sjelden ser hevdet (men som jeg lenge har hatt interesse for): nøytral monisme. Ifølge monismen er bevissthet identisk med visse hjerneprosesser. Den forkaster altså forstillingen om at psyke og soma er radikalt forskjellige. Et slikt monistisk standpunkt er i seg selv ikke uvanlig; tvert imot, det dominerer dagens filosofiske debatt. Men de aller fleste monister hevder at bevisstheten «egentlig bare» er noe fysisk; de er fysikalister. Nøytrale monister derimot, argumenterer for at virkeligheten i seg selv neppe er verken rent fysisk eller rent mental; den er trolig «nøytral», men gir opphav til forestillingene om både det men- tale og det fysiske: To tilsynelatende uforenlige måter å beskrive den samme nøytrale virkeligheten på. Dermed ses bevissthetsproblemet i lys av et generelt erkjennelsesproblem som allerede Kant («Ding an sich/ Ding für mich»), Bertrand Russell og andre har påpekt: At vi aldri kan få direkte kjennskap til noe i den ytre, materielle verden. Våre opplevelser bygger jo på indirekte informasjon gjennom sanse- og hjerneprosesser, kodet i signaler som er vesensforskjellige fra det de representerer. Din oppfatning av verden, inkludert din egen kropp, er derfor konstruert av din hjerne, som en «modell» eller et «kart» over det som finnes der ute. Det eneste vi kan forvente er strukturlikhet mellom den ytre verden og vår bevisste opplevelse av den.

Det er prisverdig at Gundersen så sterkt vektlegger dette perspektivet, som jeg har savnet $\mathrm{i}$ andre nyere bøker om bevissthet. Likevel synes det tvilsomt om det er meningsfullt å hevde at de minste fysiske bestanddeler må ha iboende egenskaper som kan gi opphav til bevissthet når de kombineres. Det virker også for meg noe for upresist og pessimistisk å si at «hjernebevissthets-problemet vil forbli uløselig» ettersom vi ikke kan oppnå kunnskap om disse tilgrunnliggende egenskapene. Her er det vel (som så ofte ellers) rom for ulike grader av forståelse, og tross alt håp om at vi i betydelig grad kan øke vår forståelse og kunnskap, spesielt om hvilke typer hjerneprosesser som gir opphav til bevissthet, til forskjell fra de mange som er ubevisste. Jeg savner en grundigere diskusjon av slike nevrale korrelater til bevissthet. Og ikke minst: Jeg savner en drøfting av begrensningene $i$ vår menneskelige intuisjon og dermed den fundamentale usikkerheten $i$ alle våre filosofiske spekulasjoner. Men alt $i$ alt er dette en bok som jeg varmt vil anbefale alle som er fascinert av det som er blitt kalt «den største intellektuelle utfordring i det nye årtusen» (1).

\section{Johan F. Storm}

Fysiologisk avdeling

Institutt for medisinske basalfag

Universitetet i Oslo

\section{Litteratur}

1. Dehaene S, Changeux JP. Neural mechanisms for access to consciousness. I: Gazzaniga M, red. The cognitive neurosciences. 3. utg. New York: Norton, 2004:1145-57

\section{Personlighetsforstyrrelser - ikke så stabile likevel?}

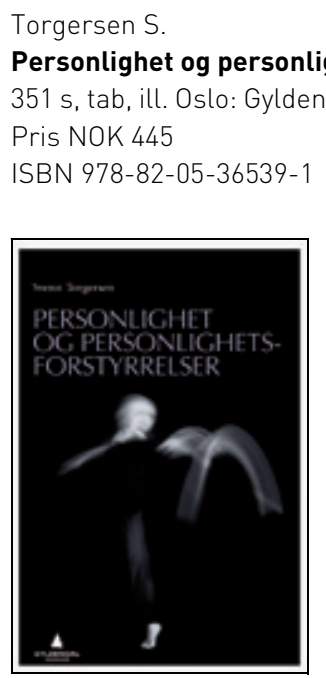

Svenn Torgersen, professor ved Psykologisk institutt, Universitetet i Oslo er en av våre mest kjente forskere innenfor personlighetspsykologi, særlig med vekt på epidemiologisk forskning. Hans bok om personlighetsforstyrrelser som kom første gang i 1995, er blitt en sentral lærebok for ulike grupper helsearbeidere, spesielt for leger og psykologer. Denne kommer nå i revidert utgave, ajourført for nyere epidemiologisk og nevrobiologisk forskning. Vi vet i dag langt mer om forekomst og kan dessuten - ifølge Torgersen - studere individuelle forskjeller på grunnlag av genetiske variasjoner, hjernestruktur og nevrotransmittere.

Som tidligere er boken bygd opp som en reise fra undersøkelse av personlighetsbegrepet og tydeliggjøring av de sentrale personlighetsdimensjonene til gjennomgang av ulike typer forstyrrelser - $\mathrm{i}$ stor grad hentet fra DSM- og ICD-10-diagnostikk. Torgersen omsetter dette i gjenkjennelige kliniske typologier med ord hentet fra hverdagslivet. Det er kapitler om epidemiologi og om forløp av forstyrrelsene, om sammenheng mellom de ulike typene og om årsaker. Han drøfter mulige sammenhenger mellom symptom- og personlighetsforstyrrelser og har dessuten avsluttende kapitler om behandling og om overordnede vurderinger av forstyrrelsenes natur.

Styrken i denne utgaven, som i den forrige, er Torgersens evne til å kombinere synsvinkler. Det er imidlertid også svakheter som trer tydeligere frem nå enn tidligere. Ertende utfall mot psykoanalytiske forståelsesformer er mindre forfriskende i dag enn for 15 år siden. Fagfeltet preges i dag lite av motstand mot diagnoser og tester. Enkelte vil hevde at det typiske mer er kritikkløs akseptering. Personlighets- 
mønstrene er ikke stabile slik vi trodde, skriver Torgersen. En så viktig observasjon bør begrunnes bedre enn ved å vise til avbleking med aldring og til at mønstrene kan influeres av symptomlidelser og belastninger. Torgersen forsøker å konkretisere konsekvensene av personlighetstyper i hverdagen ved å beskrive samspill i parforhold. Han har, skriver han på side 153, valgt litt ekstreme eksempler som ligger nær opp til våre kjønnsrollestereotypier. Hensikten er å tydeliggjøre mønstrene. Jeg prøveleste dette høyt for en kollegagruppe som reagerte mer med vantro munterhet enn med forståelse. Behandlingskapitlet er dessuten lite gjennomarbeidet. Den som ønsker å lære om dette, trenger en grundigere og mer fullstendig tekst.

Min samlede vurdering er derfor at boken hadde tjent på en mer omfattende revisjon. Gammelt tankegods kunne med fordel fjernes samtidig som nyere forskning kunne presenteres bredere - og kanskje med den kritiske analytiske tilnærmingen som tidligere har vært et av Torgersens varemerker.

Men for all del: Dette er fortsatt en spennende og kunnskapsrik innføring i og drøfting av personlighetens ulike dimensjoner og mønstre.

\section{Ny utgave av norsk lærebok i medisinsk mikrobiologi}

Degré M, Hovig B, Rollag $H$, red

Medisinsk mikrobiologi

3. utg. 803 s, tab, ill. Oslo: Gyldendal Akademisk, 2008. Pris NOK 795

ISBN 978-82-05-31590-7

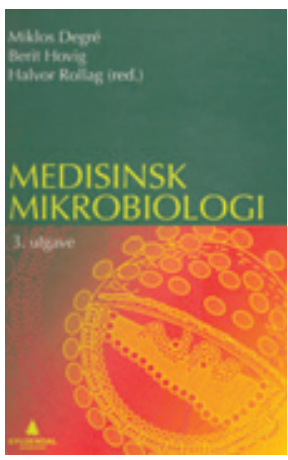

Dette er 3. utgave av en lærebok i medisinsk mikrobiologi som er beregnet på medisinstudenter. Den er skrevet av spesialister som har årelang erfaring i undervisning av legestudenter, har bred erfaring og oversikt over

faget og evner å formidle dette i sin bok

Faget medisinsk mikrobiologi er i rask utvikling, både fordi det stadig oppdages nye mikrober og ny kunnskap erverves om utbredelsen av smittestoffene. Dessuten skjer det en kontinuerlig utvikling innen mikrobiologisk diagnostikk og behandling av infeksjonssykdommer, slik at det nå igjen er påkrevd med en ny utgave av læreboken.

Den nye utgaven har samme oppbygning og de samme kapitlene som den forrige, som for øvrig var svært omarbeidet i forhold til førsteutgaven. Selv om ingen nye kapitler er kommet til siden sist, er det mye nytt stoff. Spesielt er de kapitlene som omtaler antibiotikabehandling oppdatert med nyheter innen antibakterielle midler, antiviralia og resistensutvikling.

Boken har mange tabeller og illustrasjoner som gjør stoffet lettere tilgjengelig, men har ingen fargebilder eller plansjer slik man kan finne i de fleste nyere lærebøker.

For de av leserne som ønsker å fordype seg i stoffet, er det i denne utgaven tatt med referanser til utdypende litteratur etter hvert kapittel.

En stor fordel med å lese en norsk lærebok i medisinsk mikrobiologi er at stoffet er tilpasset norske forhold. Utbredelsen av smittestoffer er svært forskjellig i ulike deler av verden, og fagstoff $i$ for eksempel en amerikansk bok kan ikke direkte overføres på norske forhold. Denne boken formidler kunnskap om de norske epidemiologiske forhold og vår kliniske praksis.

Utover målgruppen legestudenter, vil mange andre som interesserer seg for dette fagfeltet kunne ha nytte av å lese den.

\section{Susanne Gjeruldsen Dudman}

Avdeling for virologi

Nasjonalt folkehelseinstitutt

\section{En ny Semmelweis?}

Kendrick M

\section{Det store kolesterolbedraget}

Hva gir deg egentlig hjertesykdom - og hvordan unngår du det? $267 \mathrm{~s}$, tab, ill, Oslo: Forlaget Lille Måne, 2008. Pris NOK 329

ISBN 978-82-92605-60-8

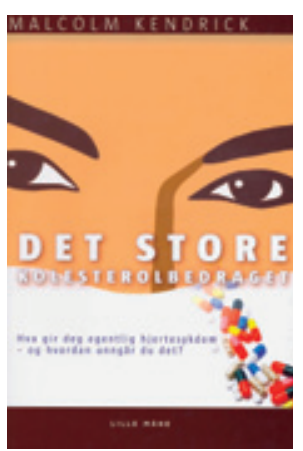

Forfatterens målgruppe synes å være alle, både leg og lærd, som er blendet av at kolesterolhypotesen nå er bevist etter ca. 100 års forskning. Selv om boken også henvender seg til ikke fagorienterte, tror jeg at lesere uten god basal kunnskap i lipidmetabolisme og hjerte- og karsykdommer vil ha problemer med å følge forfatteren og hans argumentasjon gjennom de 11 kapitlene og 267 sidene. Et forord er forfattet av spesialist i radiologi Tor Ole Kjellevand og et etterord av Dag Viljen Poleszynski, fagredaktør i Mat \& helse. Boken er godt oversatt av Tone Bøstrand.

Boken har stive permer og enkle relevante illustrasjoner. De første 200 sider og åtte kapitler er et systematisk angrep og forsøk på å bortforklare det som ligger til grunn for at majoriteten av forskere i dag vil hevde at kolesterolhypotesen er bevist.

Teksten på smussbindet forteller at forfatteren $\mathrm{i}$ en strålende opplagt form og bitende skotsk humor, bevæpnet med (etter egen oppfatning) faktakunnskap setter nådestøtet mot det rådende kolesterolparadigmet og tilbakeviser mytene om hva som forårsaker hjertesykdom. Avsløringer om de tette økonomiske båndene som eksisterer mellom den farmasøytiske industrien og legevitenskapen, understreker ifølge forfatteren hvorfor statiner ikke har noen plass i dagens medisin.

Forfatteren prøver å vise at mettet fett $i k k e$ øker kolesterolnivået i blodet, at kolesterol ikke tetter blodårene og at statiner ikke senker kolesterolnivået og gir liten eller ingen beskyttelse mot hjerte- og karsykdommer. Teksten på smussbindet lover at dersom «du er en av mange nordmenn (ca. 400 000, data fra SLV 2008) som daglig tar kolesterolsenkende medisiner (statiner) kan denne boken bokstavelig talt redde livet ditt». «Den skal gi deg kunnskapen du trenger for å sove godt om natten» ( . . og kanskje ikke våkne om morgenen?). Argumentene er fremført med stort engasjement, men jeg er prinsipielt uenig med påstanden $i$ forordet om at det Kendrick skriver er vitenskapelig dokumentert. Hvis så skulle være tilfellet, har norske helsemyndigheter, Helsedirektoratet, Statens legemiddelkontroll og Kunnskapsenterets forskjellige utvalg en jobb å gjøre med den konspirasjonbevegelse de har vært utsatt for. Jeg følte meg faktisk flere ganger hensatt til Ludvig Holbergs tekst og Erasmus Montanus' argumentasjon. Det skal ikke være plass for denne anmelderen til å forme en bokanmeldelse som et motinnlegg. Det var derfor med stor interesse jeg leste bokens siste tre kapitler med overskriftene: Hva er årsaken til hjertesykdom? Stresshypotesen - stemmer den med fakta? Andre former for stress. Her er faktisk forfatteren på linje med resultatene fra den store pasient-kontroll-studien INTERHEART som registrerte risikofaktorer for første hjerteinfarkt - og som omfattet totalt 27098 menn og kvinner. Men nå forsvinner risikofaktorer som røyking, hypertensjon, diabetes, abdominal overvekt, fysisk aktivitet, lipider (apo B/apo A1) og «high risk diet» (mettet fett) i Kendricks forklaring på årsaken til hjertesykdom. Statens Institut for Folkesundhet i Danmark har nylig beregnet hvor mye bl.a. stress og belastninger på jobben reduserer den forventede levetid: hos menn med fem år og hos kvinner med to år. Så stress betyr mye i Danmark men viktigere er røyking, fysisk inaktivitet, høyt blodtrykk, lavt inntak av frukt og grønt, for mye mettet fett bl.a. De samme risikofaktorer som i INTERHEART-studien. Det «glemmer» Kendrick i sin bok.

Boken kan ikke anbefales til hjertefriske eller hjertesyke pasienter, men til allmenn- 